\title{
The Establishment Urgency of Drinking Water State-Owned Enterprises After The Cancellation of Water Resources Law
}

\author{
Siska Purnianti \\ Ministry of Public Works and Housing \\ Indonesia \\ siskapurnianti@gmail.com
}

\begin{abstract}
To achieve the condition of people who live healthy and prosperous in the future, both in urban and rural areas, will require the availability of drinking water which is sufficiently sustainable. Drinking water as a source of human life needs to be managed in a better way that can provide health and wellbeing for the whole people in Indonesia without exception. Central and local government should be able to guarantee the health and welfare of the urban and rural people through quantity, quality and accessibility of clean and drinking water. The Strategic problems of drinking water supply system after the cancellation of Water Resources Law are the role of local government and the obligatory role of Regional Drinking Water Companies (PDAM) become bigger, while not all local governments and PDAM has a good performance condition, such as some aspects : technical, financial, services, operational, and human resources. According to that problems, the Government Regulation about Drinking Water Supply System gives a mandate that the government could establish the Drinking Water State - Owned Enterprises to develop and improve the accessibility to clean and drinking water for all people in Indonesia without exception. The purpose of this research is to analyze the urgency of Drinking Water State Owned Enterprises establishment from the legal analysis, whether it can have a positive impact for dringking water policy to achieve $100 \%$ public access to clean and dringking water before 2019. The method of this research approach is juridical empiric research.
\end{abstract}

Keywords-Component; Dringking Water; Government, Drinking Water State - Owned Enterprises, Regional Drinking Water Companies

\section{INTRODUCTION}

Clean water is a basic need to support human life, especially for drinking water. In the National Medium Term Development Plan 2015 - 2019, the Government of Indonesia targets $100 \%$ access to drinking water (universal access) for the community through pipeline network system and Non Pipeline System Network.
Currently, access to drinking water is only $73.7 \%$. To support the movement to reach $100 \%$ access to drinking water required an investment scenario of Rp 253.8 Trillion with the proportion of the $20 \%$ allocation of funds from the State Budget and Revenue (APBN) Ministry of Public Works and Housing, 47\% Regional Budget and Revenue (APBD), $8 \%$ of Cooperation with Private Enterprise, 7\% of Corporate Social Responsibility (CSR) and Regional Drinking Water Company (PDAM), 6\% from Special Allocation Funds (DAK), and 5\% from banking loan. In addition, fulfillment house connection (SR) becomes important in meeting the target of RPJMN 2015-2019. Presently, the piped water network reaches only 11 million SR, whereas 27.6 million is needed SR to target $100 \%$ access to drinking water is reached [1]

\begin{tabular}{|l|c|c|}
\hline \multicolumn{1}{|c|}{ Financing source } & IDR (Billion) & $\%$ \\
\hline State Budget and Revenue & 33.899 & $13 \%$ \\
\hline Raw Water & 18.199 & $7 \%$ \\
\hline PPP Pinjaman \& B-to B & 20.153 & $8 \%$ \\
\hline Banking Loan and & 11.446 & $5 \%$ \\
\hline CSR Region & 17.351 & $7 \%$ \\
\hline $\begin{array}{l}\text { Regional Budget Water } \\
\text { Revenue }\end{array}$ & 18.287 & $47 \%$ \\
\hline $\begin{array}{l}\text { Drinking Company } \\
\text { Special Alocation Funds }\end{array}$ & 15.397 & $6 \%$ \\
\hline TOTAL Source: Direktorat Peng & $100 \%$ \\
\hline
\end{tabular}

Source: Direktorat Pengembangan SPAM Kementerian PUPR, 2016

The strategic issues of the Drinking Water Supply System implementation from general strategic problems, technical, institutional and financial issues are include:

1. The growth rate of urban population higher than the growth rate of urban drinking water access, which led to lower 
coverage of piped drinking water services and the increasing of needs for drinking water per capita. [2]

2. The revocation of Law Number 7 Year 2004 that obstructed the development and cooperation between local governments and the role of the private sector in the provision of drinking water. [3] The quality of water that were received by PDAM customers was still clean water quality, not yet qualified as drinking water quality directly. [4]; [5]; [6]

3. Drinking Water Supply Partnerships between Government and Community was less developed; [7]

4. Most urban areas do not have sufficient sources of raw water to supply the needs of clean or drinking water. Therefore, to meet the needs of raw water, there are still many urban areas that depend in the surrounding areas; [4]; [8]

5. Number of Non Revenue Water was still high, nationally the rate of water loss by 2015 was $32,10 \%$; [4]; [8]

6. Number of idle capacity was still high, nationally the average of idle capacity was $37.900 \mathrm{Liter} /$ second until mid-2017; [4]; [1];

7. The energy costs that was spent by the PDAM have not been efficient yet (reaching an average about $30 \%$ of total operating costs); [4]

8. The applied water tariff was lower than the cost of production;

9. Investments in PDAM to this days have been more dependent on central and local government funds (APBN and APBD) rather than PDAMs internal funding source, because the profit that could be obtained by PDAM was only $10 \%$ of earning assets according to Minister of Home Affairs Regulation Number 23 Year 2006 on Technical Guidelines and Procedures for Regulating Drinking Water Tariffs on PDAM, as well as uncooperative collaboration between Local Government and Regional People's Representative Assembly

(DPRD) in order to re-deliver that profits back to the PDAM, with the result that making it difficult for PDAM to have own internal capital.

10. Many local governments have low fiscal capacity so that could not provide sufficient funding support (Regional Fund of common Affairs) for SPAM development

PDAM as the backbone of drinking water supply in the local area, needs good performance so that it can provide adequate services for the public and can meet the standard of service required. Therefore, the improvement of PDAM from both technical and non-technical aspects must be immediately fixed. One of the non-technical aspects of SPAM is good organizational management. With the limited capacity of PDAM and the high level of pressure on PDAM both internally (operational processing, management, and service) and external, it is necessary for government to attempt and intervene in providing alternative solutions to the improvement of SPAM organization performance as soon as possible.

The government also evaluateed that piped drinking water supply should have $4 \mathrm{~K}$ principles (Continuity, Quality, Quantity, and Affordability) as the important factor in the provision of drinking water. The demand for drinking water quality compliance in accordance with Government
Regulation No.82 of 2001 on Water Quality Management and Water Pollution Control,

it made the cost of drinking water treatment high and gave impacts on high sales tariff to customers. However, government should, in essence, consider the publics ability to pay and obtain access to drinking water. On the other hand, PDAM as the SPAM provider must think about the technical as well as other operational costs issues .

Government Regulation Number 122 year 2015 on Drinking Water Management System (SPAM), states that the enforcement of SPAM implementation can be by the StateOwned Enterprises (BUMN). Based on this, the government sees the possibility to reduce the financial pressure that were faced by PDAM with establishing an alternative institution or business entity that will can handle the SPAM management, especially raw water provision and management also its processing units to the distribution network of clean water. Through this plan, PDAM will be expected to focus on optimizing services to customers.

In the present condition, there are several implementing institutions for drinking water supply for the public, namely Perusahaan Daerah Air Minum (PDAM), SPAM Regional Technical Service Unit (UPTD), Regional Public Service Agency (BLUD), Water Supply and Sanitation System Management Board (BP SPAMS), which is usually the provision of community-based SPAM in rural areas that were not covered by PDAM and also private sector / business entity

Implementation of Drinking Water Supply System (SPAM) is the responsibility of central government and / or local government in accordance with their authority. For local governments, the provision of drinking water through SPAM is one of the mandatory governmental affairs related to basic services in the public works sector.

In principle, SPAM was organized for the purpose of :

1. availability of drinking water services to fulfill people's right to drinking water;

2. the embodiment for good quality drinking water provision and service at an affordable price;

3. Achieving balanced interests between customers and BUMN, BUMD, UPT, UPTD, Community Groups, and Business Entities; and

4. Achieving effective and efficient water efficiency to expand the coverage of drinking water services. In this study, more identification issue will identified focused on the problems encountered in the SPAM implementation and development by PDAM furthermore the establishment urgency of drinking water state - owned enterprises after the cancellation of water resources law.

\section{MATERIAL AND METHODS}

The authors conducted with sociolegal method. [9]) Conditions for the implementation of the Drinking Water Supply System will be explored through surveys to several areas that used as research sites, namely to the Regional Government on the related work units and PDAM in Bengkulu 
Province that include Bengkulu Municipality, Bengkulu Utara, Seluma, Kepahiang and Benteng District; Central Java Province include Semarang Municipality, Ungaran, and Demak District; West Nusa Tenggara (NTB) Provinces that include Mataram Municipality, West Lombok, Nirth Lombok; the Province of Jakarta, also Supporting Agency for The Develoment of Drinking Water Supply System (BPPSPAM); Indonesian Drinking Water Companies Association (PERPAMSI); Ministry of Jome Affairs, Drinking Water Supply System Directorate Ministry of Public Works; National Development Planning Agency; and Coordinating Ministry for Economic Affairs. The primary source of prospective respondent information was obtained from PDAM. The survey was primarily aimed at the obstruction and supporting factor about SPAM implementation by any parties especially PDAM, so it can be analyzed how urgent the establishment of drinking water state - owned enterprises in replace of several PDAM key roles in order to achieve $100 \%$ access to drinking water for people without exception.

\section{RESULTS AND DISCUSSION}

\section{A. PDAM}

PDAM is a Regional Owned Enterprise (BUMD) whose capital was owned by local government and has an important role as a pioneer in drinking water business sectors that have not been interested by private entities. The authority of the local government as the holder of jurisdiction may conduct "policy intervention" in a positive context regarding the performance of the PDAM through the Supervisory Board.

PDAM as a regional company was expected to play a role in maximizing the potential of the region, especially in carrying out the role of local government in providing drinking water services to the public. The main tasks and functions of the PDAM were dependent on the relevant Local Government objectives in establishing the PDAM. Some examples of basic tasks and functions of PDAM can be seen when the author did the survey to the PDAM that become the sample research.

Task and function of PDAM in general was to carry out drinking water supply with quality, quantity and continuity accordingly standard of set service and organize drinking water to improve the welfare society from social, prosperity and public services aspects.

Viewed from the PDAM general task and function, it can be said that the main task and function of PDAM was to provide drinking water services to the public with adequate quality, quantity and continuity in order to improve the welfare of the society. The PDAM was headed by a Director elected by the Regent / Mayor after through the fit nd proper test. The number of directors in a PDAM depends on the number of customers it served, in accordance with the Minister of Home Affairs Regulation Number. 2 Year 2007 on Organization and Employment of Regional Water Company. The number determination of Directors shall be based on the principles of efficiency and effectiveness of PDAM management and arrangementt.
The PDAM Director was directly responsible to the Local Government through a Supervisory Board that established and selected by the Local Government through a fit and proper test. As a BUMD that provides drinking water services, PDAM linked to various stakeholders, both at the central and local levels. The number of related stakeholders can be seen in the following figure.

\section{Figurze 1 : PDAM Institutional Relations}

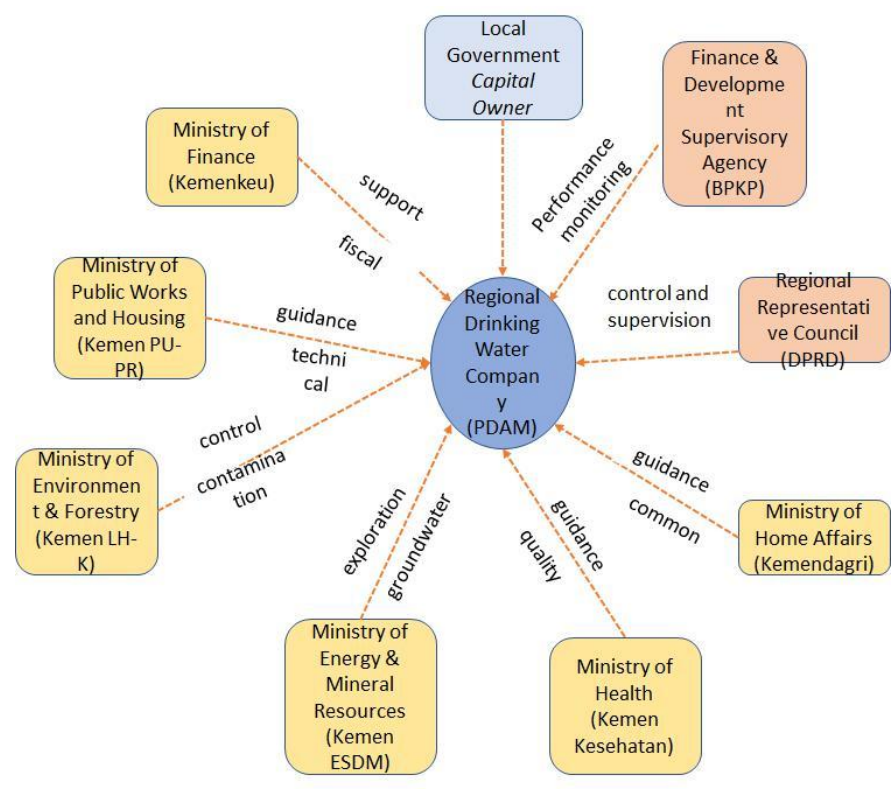

In the picture above clearly shows the function of each stakeholder and was sufficiently illustrated the complexity of PDAM management as a Regional Owned Enterprises (BUMD). A strong institutional management system with adequate human resources is essential to answer these institutional challenges. As one of the providers of drinking water services, plans, programs and SPAM development strategies by PDAM, it is necessary to know by the local government in order to synchronize the planning with other non-piped water programs that will be run by the local government. This can be stated in the Master Plan of Water Supply System (RISPAM). Based on Law Number 23 Year 2014 on Regional Government, BUMD is a business entity in whole or in part owned by regional capital. Based on Article 332 Paragraph (1) of Regional Government Law, Source of PDAM's Capital BUMD can be sourced from:

a. regional equity participation;

b. loan;

c. grant; and

d. other sources of capital, namely:

reserve capitalization;

gain revaluation of assets; and

share premium.

In Minister of Home Affairs Regulation Number 13 year 2006 on Guidelines For Regional Financial Management, the share of profit on capital participation in BUMD become the object of revenue for the original revenue in the form of the area's 
wealth results management that has been separated. Meanwhile, in Minister of Home Affairs Regulation Number 23 year 2006 on Technical Guidelines and Procedures for Regulating Drinking Water Tariffs, a reasonable rate of profit was achieved base on the profit ratio to productive assets by $10 \%$ (ten percent). This profit becomes the right of the region and depoosited into the regional funds stock after authorized by the regional head as the Regional Representative for the capital owner.

The profit of the Regional General Company shall be used for reinvestment in the form of improvement, enhancement and expansion of physical and non-physical infrastructure and facilities as well as to increase the quantity, quality and continuity of public and basic services also piloting efforts.

At this time, PDAM has applied Financial Accounting System

- Entity Without Public Accountability (SAK-ETAP) which was expected to facilitate PDAM in preparing Financial Statement. The application of SAK-ETAP aimed to enable PDAM to focus more on the development and improvement of drinking water services to the public without getting any trouble in the complexity of the Financial Accounting Standards.

The following will analyze the supporting factors and inhibiting the implementation of SPAM by PDAM:

1. Human Resources

a. Selection of Directors and Supervisory Board

The selection of Directors in PDAM has been done in accordance with Minister of Home Affairs Regulation Number 2 year 2007 on The Structure Organization and Human Resource of Regional Water Company which stated that it should be a fit and proper test conducted on the candidate for directors by an experts team that appointed by the Regional Head. The decision of the chosen directors was the authority of the Regional Head as determined by a Decree of the Regional Head. The selection system of directors will be susceptive to conflicts of interest as well the practice of Corruption, Collusion and Nepotism (KKN) because there was no or lack of team experts independence who conducted fit and proper test. On the other hand, this conditions can create good relations, in a positive sense, between the local government and PDAM but this can be non-conducive if there was a replacementThe Head of Region, whowas the elected director not in line with the new Regional Head.

Directors composition in accordance Minister of Home Affairs Regulation Number 2 year 2007 on The Structure Organization and Human Resource of Regional Water Company has been quite good Because considering the efficiency and effectiveness of PDAM management. Elections of the PDAM Supervisory Board in accordance with that regulation was also appointed by the Head of Region but not through the process of fit and propera test.

This condition can lead to unprofessional management of PDAM, due to the overall "tops" of the Directors and the Supervisory Board selected was the choice of the Regional Head, so that monitoring and evaluation of PDAM performance can not be effective. These conditions can be changed by making changes to existing regulation or the preparation of new regulation. This is could be done refer to Article 335 Paragraph (2) of Law Number. 23 Year 2014 on Regional Government. The article mandates the establishment of an implementing regulation in the form of government regulations about organs of general enterprises of the Region. a. Employee Status

PDAM employees are not Civil Servants where the election and appointment of employees were done by PDAM management. PDAM employees consist of permanent employees and contract employees. The lack of career level in the PDAM and there were no "reward and punishment" approach that has been applied for PDAM employees, it has resulted poor performance of PDAM employees. As a regionowned company, PDAM employees are often entrusted with inadequate quality with educational background that was not in accordance with the required by the company, so that the existence of this PDAM employee can reduce the performance of PDAM both in terms of service and finance.

\section{b. Employee Ratio to Customer}

The employee per customer ratio was one of the PDAM performance assessment indicators that illustrated how much labor usage efficiency was in serving every 1000 customers. From the conditions in the field, PDAM was still not able to manage the efficiency of employees so that it affected to financial burden weight in bear the cost of salary. PDAM with healthy performance had employees ratio average every 1000 customers was under 10.

Based on 2015 data, the ratio of employees per 100 customers on average national level of 5.41. This ratio is good enough because its value is less than 10, but this condition is not evenly distributed in every PDAM. Best ratio (lowest) of 2.13 occurred in PDAM Surya Sembada Surabaya, while the ratio worst (highest) of 45.45 occurred in PDAM Kota Dumai.

Figure 2 : Jumlah PDAM Berdasarkan Status Kinerja \& Rasio Pegawai

\begin{tabular}{|l|c|c|c|c|c|}
\hline $\begin{array}{l}\text { PERFOR } \\
\text { MANCE }\end{array}$ & $<=6$ & $\mathbf{6 - 1 0}$ & $\mathbf{1 0 - 1 4}$ & $>\mathbf{1 4}$ & $\begin{array}{l}\text { TOT } \\
\text { AL }\end{array}$ \\
\hline HEALTHY & 104 & 82 & 8 & 2 & 196 \\
\hline $\begin{array}{l}\text { NOT } \\
\text { HEALTHY }\end{array}$ & 4 & 56 & 30 & 11 & 101 \\
\hline SICK & 3 & 20 & 20 & 27 & 65 \\
\hline $\begin{array}{l}\text { TOTAL } \\
\text { PERCENTA } \\
\text { GE }\end{array}$ & 111 & 158 & 58 & 40 & 367 \\
\cline { 2 - 5 } & $30,2 \%$ & $43,1 \%$ & $15,8 \%$ & $10,9 \%$ & \\
\hline
\end{tabular}

Source : PDAM Performance 2015, BPPSPAM 


\section{Figure 3 : Relationship of Employee Ratio to PDAM} Performance

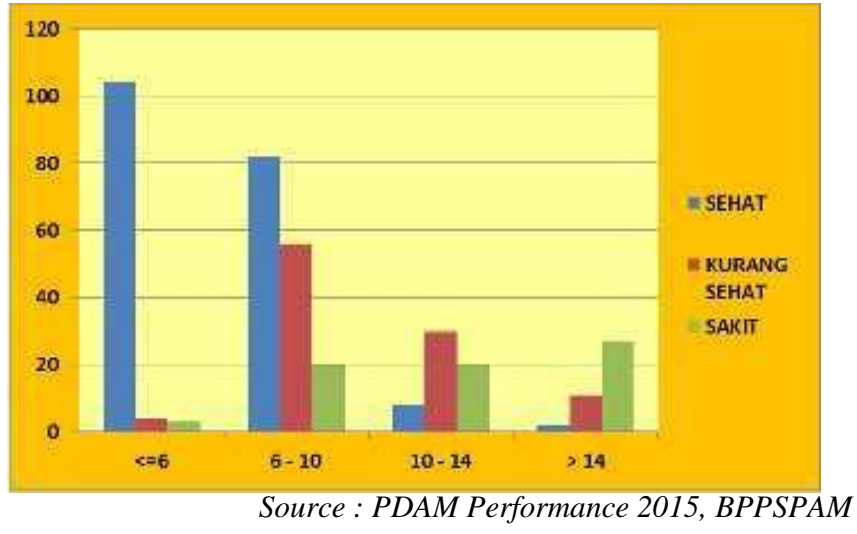

From the picture above it appears that it is necessary to decrease the ratio of employees to about 98 PDAMs $(26.7 \%)$ to be able to improve their performance status.

c. Increasing Efforts Employee Capacity

Generally it can be said that PDAM performance for human resource aspect is still very low. The capacity of PDAM employees who have been perceived to be inadequate was not a concern for PDAM to improve their staff capacity.

This can be seen from the data of BPPSPAM audit year 2015 where the ratio of education and employee training that measures company awareness to improve employee competence was very low, where more than 50\% PDAM has score 1 of the rating based on 1 - 5 scale. Meanwhile the company's concern to fund employee capacity building was also very low, it can be seen from the education and training cost ratio were more than $80 \%$ got 1 score or bad score.

Human resource as the main role of business should become the PDAM's major concern. The development of technology and information needs to be followed by all PDAM's employees to be able to increase their capacity to then improve the performance of PDAM more widely. Unequal availability of experts for PDAM was still a problem. Technical, planning, finance and administrative experts who were hard to find in these areas. Therefore, there should be some efforts from PDAM and local governementso on as the owner of PDAM to be able to improve their employees capacity through training, education, and so on.

1. Finance

a. Financial Management System

Some of PDAM financial management system has applied the Financial Accounting Standards - the Public Accountability Entity (SAK-ETAP), which means that PDAM are considered to be entities that do not have significant public accountability and publish financial statements for general purposes only for external users, but definitely needed for internal purposes, especially for directors and regulatory bodies. The implementation of SAK-ETAP would facilitate the Regional Water Company (PDAM) in preparing the financial statements. In SAK-ETAP the arrangement and calculation would be simpler as it was intended for middle to low-end businesses. This system, PDAM can be more focused on developing drinking water systems and investments for service expansion without getting caught up in the complexity of the Financial Accounting Standards.

b. Corporate Financial Performance

The PDAM financial performance will be viewed from the financial score at the time of the audit PDAM performance in 2015. This financial aspect was seen from the level of profitability (including Return of Equity and Operating Ratio), liquidity (including Cash Ratio and Billing Effectiveness), and PDAM's solvency. In general, Return of Equity and Operating Ratio of PDAM was bad. Return on Equity (ROE) was one of the common indicators used to know the extent the profitability of a company by comparing Net Profit to Total Equity.

The greater the value of RoE the better the level of profitability. Based on PDAM performance in 2015, most PDAMs (218 PDAMs) have a RoE of less than 0, which means that most PDAMs suffer losses so that their net income becomes negative. While the Operating Ratio is an indicator that can show how far the PDAM management can perform efficiency / control of operating costs and how far the PDAM management can make efforts to increase income so as to generate sufficient income to cover operating costs. Operating ratio is said to be good if its value is less than 0.5 .

From the above data it appears that none of the PDAMs have an operating ratio of $<0.5$. Most PDAMs (219 PDAMs) have an operating ratio of more than 1 which means that operating costs are greater than operating income.

This suggests that in general PDAMs have low rates of rentability where PDAMs are still unable to guarantee their financial benefits and sustainability. The Cash Ratio was one of the indicators to see the liquidity of the PDAM or the PDAM's ability to meet its short-term liabilities. Cash ratio was stated to be good if it has a number greater than $100 \%$ or in that sense cash and cash deposits were owned was greater than the current debt held. For 50\% of PDAM, cash ratio have been very good (>100\%), but there were still about $37 \%$ of PDAM with low cash ratio $(<40 \%)$. With this poor cash ratio, PDAM could not make short-term loans.

The effectiveness of billing was good because nowadays many PDAM have more than $85 \%$ billing effectiveness. This can happen because many PDAM have cooperated with commercial banks, regional development banks and PT POS to serve the payment of drinking water bills. Actually PDAM assets in 2015 are huge ( $R p 479$ trillion) and can be used to make long-term loans.

Nevertheless, in real terms, this asset can not be used as collateral for long-term debt repayment because the asset belongs to the local government and it was also used for public services, so that was making it difficult for investors to accept this asset as a debt or loan guarantee

c. Alternative Funding Sources

Various sources of financing for SPAM development are derived from APBN (Directorate General of Water Resource and Directorate General of Human Settlements), APBD, 
PDAM itself, PPP schemes, commercial banking loans, corporate social responsibility (CSR), and even from Special Allocation Fund (DAK). With enough alternative financing sources, if SPAM development would be utilizing several sources of financing then it would be required accurate planning so that it can be sure that the portion of each source of financing can be met in accordance with the expected schedule.

d. Effectiveness of Investment Financing

The World Bank study results are Publix Expenditure Review [10], by 2015 the total national government spending on the water and sanitation sector is 16 trillion rupiah or about $0.2 \%$ of Gross Domestic Product (GDP). This condition caused Indonesia to be one of the lowest countries for investing in the drinking water and sanitation sector. In spite of this value developed significantly compared to year 2005 ( Rp 5.6 trillion), however the development of access to drinking water did not increase significantly. This was happened because government investation was more focused on the production unit and unable to encourage investment from local government and PDAM to increase distribution and house connections.

For the year 2016 to 2019, the Government was targeting to fund the state budget for the drinking water sector about Rp. 52 trillion to add 4.3 million connections. From this investment value was expected to encourage investment from various other financing sources so that needed a framework of water investment. This framework was expected to "manage" investments from various sources of financing to create effective and efficient utilization of financing sources in increasing the coverage of drinking water services.

2. Technical Aspects

a. Efficiency Capacity Utilization

Idle Capacity was the capacity of processing that can not be utilized, the amount obtained from the installed capacity that was reduced by the production capacity. The main problem of idle capacity was generally caused by the installation which was decreasing its performance or decreasing the capacity / availability of raw water source.

According to the Water Supply System Development Supporting Agency / BPPSPAM (2015), unused water capacity in PDAM was still high at 38.000 liters / sec. Idle Capacity was the largest in Central Java, reaching 7,574 liters / second, followed by West Java and East Java. To overcome this, BPPSPAM prefers to focus on utilizing Idle Capacity rather than having to find new sources of raw water or to build new installations or improve processing capacity (uprating).

Idle Capacity number when converted into the number of Home Connection (SR) can reach 8.5 million SR with the assumption of water usage of $100 \mathrm{~L} /$ person / day and the number of person per house connection of 5 people. This means that if there was one PDAM in one area and there was idle capacity, it means that PDAM can still develop the number of cutomers, or expand the scope without having to create a new installation. At this time the prevention of idle capacity was done through the strategy as shown in the picture below
Figure 4 : Idle Capacity Control Strategy

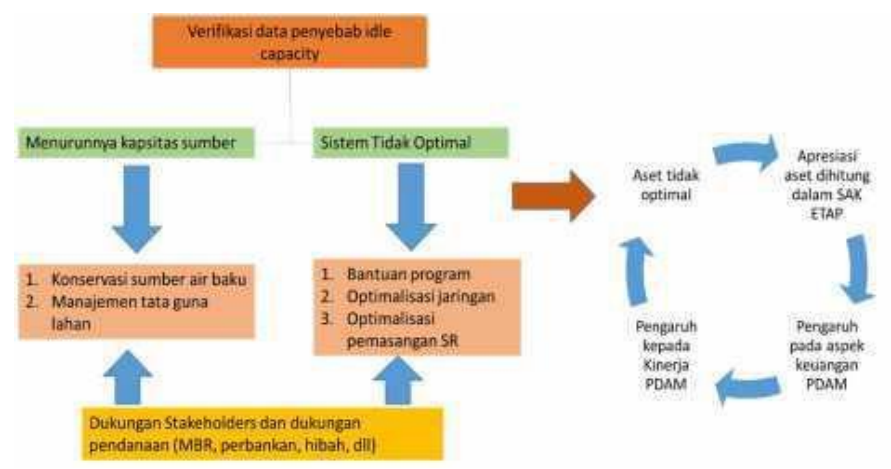

Source : Directorate of Water Supply System Ministry of Public Works and Housing-Workshop on Preparing the Implementation of Drinking Water Grant Program APBN, Jakarta, October $7^{\text {th }}, 2015$

Unutilized installed capacity might indicated inefficient processing performance and this may lead to potential revenue loss.

b. Water Loss Rate (Non Revenue Water)

According to the International Water Association (IWA), the problem of water loss was a problem in almost all drinking water management in the world. It was said that the topic of the 21 st century was the problem of water loss. Water loss can not avoided, but can be reduced, so all drinking water managersshould struggle to reduce water loss.

Non-Revenue Water (NRW) was one of the main causes of low performance of drinking water company. When calculated as the difference percentage of sold water to water distributed, the water losses of PDAM in Indonesia varies widely. Some PDAM have a water loss rate only about 20 percent or less, but many also reach 60 percent or more. [11]

From the data showed that PDAM have NRW level above $40 \%$ of 87 PDAs, while PDAM with NRW level between $20 \%$ - 40\% reach 247 PDAM. This shows that most PDAM in Indonesia have NRW levels between $20 \%$ $40 \%$. To see correlation of NRW level and PDAM performance can be seen in this image. [11]

From the data, there is some information that are: a) The high level of NRW negatively affected to the level of PDAM performance. b) PDAM with healthy performance on average have an NRW rate between 20 - 30\%. c) NRW levels above $40 \%$ were mostly PDAM that have sick performance. [11]

There are two main causes of water loss:

1) loss caused by physical piping and distribution system, caused by corrosive pipes, low pipe quality, old pipe age and unsuitable pipe depth (increasing infrastructure development), making it susceptible to damage.

2) non-physical water loss, caused by several factors, including: illegal connection, water use by the community not through water meters, unrecorded utilization in water meters and uncollected water usage (tank usage, office use. 
Leakage also often occurs because, theft of pipelines network, water meter reading system was still manual and high usage zero $\mathrm{m} 3$. In addition, the leak also occured because, there were many water meters that were buried or in the house as well as the accuracy of water meters.

This loss of water was destructive and effected to PDAM performance effectiveness. The impact of water loss, including among others:

1) Drainage to the customer's place was insufficient (flows less than 24 hours)

2) Decrease of public trust and customer to PDAM

3) Reduced sold water and water income

4) Increased operational costs, and inefficiencies in production, electricity and chemicals costs. The most prominent was the rise of drinking water that has no account.

The important thing to do in overcoming the loss of water in Indonesia among others include:

1) Strong commitment from top management / highest decision maker;

2) Detection and repair of leaks;

3) Water pressure management;

4) Control of active leakage, for example by Zoning and District Area Meter technology (DMA.

5) Speed and quality of improvement;

6) Pipe repair;

7) Asset management

The successfull of reducing the rate of water loss will increase profits and also increase the value of financial and performance value of PDAM. PDAM would get additional value if in a book year compared to the previous fiscal year and if there waere improvements to at least one of the following indicators: an increase in the ratio of profit to earning assets, an increase in the ratio of earnings to sales, increasing service coverage, and decreasing the rate of water loss and service coverage to be better.

3. Limits of Authority

Governement Regulation Number 122 Year 2015 of Drinking Water Supply System (SPAM) stated that SPAM enforcement from raw waters, productions, distributions and services units were the authority of the central government and regional governments and / or through institutional and / or legal entities that were established based on their own level. The authority in the implementation of SPAM are as follows:

a. Central Government, which was related to preparing and establishing the Cross Provincial SPAM Master Plan; norms, standards, procedures, and criteria; to establish state-owned enterprises and / or Technical Implementation Unit (UPT); also give permission to Business Entity to conduct SPAM Implementation.

b. Provincial Government, which was related to the formation of Regional Owned-Enterprises (BUMD) and / or UPTD of Provincial and give permission to Business Entity to conduct SPAM Implementation, including in production unit.

c. Within this authority, the provincial government should conduct, monitor and evaluate the implementation of SPAM and report to the central government. d. Municipality Government, which was related to the establishment of BUMD and / or UPTD of the Province and gave license to the Business Entity to conduct SPAM Implementation.

In terms of management and financing alternatives, generally the authority of various stakeholders can be seen in the scheme below:

1. Development and Management of Raw Water Units Based on Governement Regulation Number 122 Year 2015 of Drinking Water Supply System (SPAM), the authority and responsibility to guarantee the availability of Raw Water for the Implementation of SPAM has been divided according to its operational area, as follows:

1) Central government for the provision of SPAM across provinces;

2) Provincial Government for the implementation of SPAM across districts / cities;

3) Municipality governments for the implementation of SPAM in their own territories.

Under ideal conditions, the division of authority was effective enough to solve the problem that not every regency / municipality has adequate sources of raw water. However, in practice there were territorial ego about the ownership of raw water resources that obstructed the division of authority. As a strategic step to overcome this issue, the central government can take over the authority related to the development and management of raw water. The basic for this consideration was that the characteristics of water fulfillment for various needs of Water Resources through water allocation was a national strategic interest and was cross-regional (provincial and municipality/ district). To be able to implement it, it was necessary to make adjustments to the relevant regulation, such as:

1) Law Number 23 year 2014 on Regional Government;

2) Governement Regulation Number 121 Year 2015 on the Management of Water Resources

3) Governement Regulation Number 122 Year 2015 of Drinking Water Supply System

2. Development and Management of Production Units Production Unit, was an infrastructure and facilities that can be used to treat raw water into drinking water through physical, chemical, and / or biological processes. The production unit, may consist of processing buildings and equipment, operational devices, measuring and monitoring equipment, and drinking water storage buildings. Distribution unit, also consists of the system of pumping, distribution network, building shelter, measuring and monitoring equipment. Management of distribution units intended to provide certainty of quantity, quality, and continuity drainage water, which provides a 24-hour drainage guarantee per day. However in fact, PDAM never informed the quality of drinking water they provide to the customers.

The water quality that customers received was a measure that used to determine whether the water quality that were distributed by the PDAM has met the drinking water quality as stipulated in Regulation of The Minister of Health Number 492 Year 2010 on Water Quality Requirements. 
Often found that the quality of water produced in the production unit was still less qualified as healthy drinking water even in some places not even feasible to drink. Water that was worth to drink has certain requirements: physical, chemical and bacteriological, and that requirements were a unity so that if there was one parameter that did not meet the requirements, then the water was not worth to drink.

On the other hand, drinking water treatment technology that used by PDAM in Indonesia generally still use conventional system with Coagulation-Flocculation system, Fast Sand Filter and Disenfection process using chlorine compound.

The worse quality of raw water and the higher content ammonia and coli bacteria, the need for drinking water treatment chemicals also increased. The lower quality of raw water then the cost of production will be higher. The cost of production depends on the source of raw water used by the PDAM, but in general the production cost for all types of raw water was higher than the tariff as describes below :

PDAM that was using water springs as raw water sources, their average production cost was Rp $787 / \mathrm{m} 3$, while the average tariff was Rp $618 / \mathrm{m} 3$.

PDAM that was using water springs, deep wells and rivers at the same time, the average production cost was $\mathrm{Rp} 1,188 / \mathrm{m} 3$, and average tariff of Rp 1,112/ m3. While

PDAM that rely on rivers as raw water sources, the average production cost was Rp $1.665 / \mathrm{m} 3$, and average tariff was Rp $1,175 / \mathrm{m} 3$.

Therefore, the monitoring and evaluation of SPAM that was held by the government related to Norms, Standards, Procedures and Criteria must be properly implemented. The financing opportunities for this production unit can come from APBN, APBD, KPBU (PPP) scheme, and certainlyfrom internal fund of PDAM.

3. Development and Management of Service Units

The Service Unit consisted of a house connection, a public hydrant, and a hydrant fire. Measurement the service quantity of the public house and hydrant connections that should be installed the measuring instrument, that was water meter, to ensure its accuracy, water meter should be periodically appraised by the authorized institution. follows:

The authority in the implementation of SPAM were as

1) Central Government, which was related to preparing and assigning the Master Plan Cross Provincial SPAM norms, standards, procedures, and criteria; to establish state-owned enterprises and / or Technical Implementation Units (UPT); and grant permission to the business entity to conduct SPAM Implementation.

2) Provincial Government, which was related to the establishment of Regional Owned Enterprises (BUMD) and or Provincial Local Technical Implementation Units (UPTD) and grant permission to the Business Entity to undertake The operation of SPAM, including production unit, under this authority, the provincial government should do monitoring and evaluation of SPAM implementation and reporting to Central government.

3) District or City Government, which was related to the establishment of BUMD and or Provincial UPTD and grant permission to the Enterprise for Conducting SPAM.

Often the people did not get enough drinking water as a result the high number of drinking water leakage. The leakage occured due to high number of Illegal installation of water pipelines and due to water meter that was not working so that the amount of recorded water was smaller than it actually was.

Controlling and accountability for drinking water supply management was still weak, there were no sanctions for drinking water providers that did not provide services in accordance with the conditions specified. The Supervisory Board was also still lacking function.

4. Raw Water Availability

The availability of raw water is now one of the main issues faced by PDAM and other SPAM managers. Reduced raw water discharge and the decrease of raw water quality become the source of the problem. This is not regardless of the climatic changes occurring on earth. However, the impact this climate change must be mitigated, for example by safeguarding source of raw water. Reduced raw water causes the capacity of raw water that can be processed into decreased resulting in unemployment capacity due to installed capacity which previously could operate with a capacity of $100 \%$ become reduced.

Reduced quality of raw water has an impact on management performance PDAM, including the declining water production because the quality of raw water is not according to the initial design, as well as raise the cost of processing in the end can have an impact on the company's financial performance.

5. Conditions of Pipeline Infrastructure

SPAM development in Indonesia has been started since the Dutch colonial era beginning in the 20th century. Until now there are still some PDAMs that utilize buildings and other infrastructure built in that era, such as such as Semarang PDAM office, Solo City, Salatiga City and other cities. The development of SPAM by the Indonesian government has been active since the 1970s, which begins the formation of its PDAM and SPAM in the regions. Enough many pipelines were built in the 1970s and 1990s and turned out to be systems The piping is still in use today.

The current pipeline network is still largely unknown. Sometimes there is piping that is currently under the structure of the building. Some PDAM also do not have distribution pipeline network maps, mainly secondary and tertiary distribution networks. The above conditions have some effect on the performance of the PDAM or other SPAM managers, such as: high water loss rates, decreasing the quality of production water due to water pollution in piping, the difficulty performed maintenance, and so forth.

6. Service Coverage

The coverage of PDAM services in 2014 varies considerably. The scope of this service also consists of two categories, namely the scope of administrative services that constitute 
comparison between the underserved and the total population Regency / city concerned and coverage of technical services in the form of a comparison between the number of underserved communities to the number of people residing in PDAM service area.

In total, the coverage of technical services amounted to $43 \%$ (on average also $43 \%$ ) but administrative service coverage is only $26.6 \%$ (on average by $29 \%$ ). The lowest technical service coverage occurred in PDAM Kabupaten Deli Serdang which is only $3.7 \%$ with total connection number of 6,071 House Network (SR), and the highest coverage of technical services occurred in PDAM Kota Banjarmasin amounting to $99.9 \%$ with a total connection amount of $154,502 \mathrm{SR}$. When viewed from the total coverage of technical services by $43 \%$, then actually still very high drinking water services market, at least by utilizing the existing network. This becomes a homework for the central government as well as areas to improve the scope of this service. Without considering the availability of raw water and the capacity of the IPA, the total addition of SR that can be served in the technical service area with utilizing existing network system is 17 million SR.

7. User Community

a. Community Needs

The community's need for piped water at this time is highly dependent on the availability of alternative drinking water sources in the region. Increased water access drinking piping is competing with public water sources. In some areas of drinking water piping can be very easily "sold" because communities do not have a proper source of clean water / drinking water. This happens a lot in the areas of Sumatra, Kalimantan and NTT due to the difficulty of society get clean water source. But in other areas, it is very difficult to "selling" piped drinking water because the community has a source of clean water adequate, such as dug wells, drilled wells, and springs.

This community need is related to the people's desire to connect (willingness to connect (WTC) to the piped water network system. By therefore, the PDAM's role as a water supply operator needs to be developed on the marketing sector to convince the public of the importance of having connection. To improve the WTC needs to be done cooperation with instansiinstansi such as the Public Health Office to socialize or promotion of the importance of water sources that are fit for health and also the authorized agency in groundwater management to socialize reduction of groundwater extraction associated with decreasing groundwater quality or land subsidence decrease.

\section{b. Consumer Buying Power}

Consumer purchasing power in this study is associated with costs that need to be incurred a customer community that does not exceed $4 \%$ of the community's income customer. This is in accordance with Permendagri No. 23 of 2006 on guidelines technical and procedures for setting drinking water tariff on PDAM. still quite a lot of PDAM applying tariffs above people's purchasing power, yet another thing to keep in mind was the determination of this tariff was not solely based on the purchasing power of community alone but also other things like production cost, water loss rate, and also implementation of tariff classification system and progressive tariff. Assessment of the affordability of these tariffs is very useful in assessing the subsidy which must be issued by the Regional Government.

c. Water Consumption Level

This level of water consumption will be related to the effectiveness of PDAM management within utilizing the raw water resources and distribution capacity it has. When level low water consumption, it can be assumed that the existing capacity can not meet the minimum water needs of its customers. While if the level the consumption is too high then it can be said that water capacity should be produced or sold can be used to add more so that more people can use drinking water piping with a level of consumption is more feasible or not excessive.

d. Water Quality Production

The quality of water production from the PDAM has actually fulfilled the water quality requirements drink. But the quality of drinking water can not be maintained up to the customer because of the high level of leakage in the pipeline network system where the dirt and other objects from outside the pipe can enter the network. This condition causing low use of PDAM water as a source of drinking water society, especially now has a lot of available water refills, so now drinking water production from PDAM is used more for the use of activities domestic daily, such as bathing, washing and latrines.

This condition sometimes causes PDAM difficult to sell water to the public, especially if the community already has other alternative sources of clean water. Difficulty getting these subscribers will cause stalled speed increasing number of customers in PDAM.

\section{B. THE ESTABLISHMENT URGENCY OF DRINKING WATER STATE-OWNED ENTERPRISES AFTER THE CANCELLATION OF WATER RESOURCES LAW}

Submission for testing back to the UU SDAir are in case Number 085 / PUU-XI / 2013. In that case the Constitutional Court decided to grant the petitioners' petition to declare that the SDAir Law is contradictory to the 1945 Constitution of the Republic of Indonesia and has no binding legal force. This ruling also re-enacted Law Number 11 Year 1974 on Irrigation (hereinafter referred to as the Watering Law) in lieu of the Law on SDAir which has been canceled.

The cancellation of the Water Resources Law has affected several parties, among others [12]; [17]

1. Impacts for the Government

a. Implicit on the legislation as the implementing rule of the SDAir Law is no longer applicable so that as legal paying the re-enactment of Water Law;

b. The state has the right to absolute control over water so that the main priority is given to the BUMN and BUMD;

2. Impact for Water Management Enterprises 
a. The loss of legal pay as the basis for the issuance of water harvesting permits for Water Management Enterprises at both the central and regional levels;

b. For water business process must partner with BUMN or BUMD in its area;

c. Inhibition of investment climate Due to the absence of legal basis that regulates the establishment of drinking water based industry in Indonesia

3. Impact for the People

a. Positive impact in public life widely, namely that the right of people to water bias really fulfilled in accordance with the constitutional basis of NRI Article 33 of the 1945 Constitution of the Republic of Indonesia;

b. Natural wealth in the form of water is fully utilized for the welfare of society and the opportunity of commercialization of water by private companies must be regulated and closely monitored.

The cancellation of the UU SDAir has consequences for the implementing regulations under it, one of which concerns Government Regulation No. 16 Year 2005 on SPAM Development (hereinafter referred to as PP SPAM) as the basis for the implementation of Article 40 of the SDAir Law. In Decision No. 85 / PUU-XI / 2013 the Constitutional Court declared that the SPAm did not meet 6 basic principles of water resources management restriction, namely : [14]

1. Any exploitation of water shall not interfere with, override, let alone abolish the people's right to water Since the earth and the water and the wealth contained therein other than the possessed by the state, also the designation shall be for the greatest prosperity of the people;

2. The State shall fulfill the people's right to water;

3. Must remember the preservation of the environment;

4. As a production branch which controls and controls the livelihood of many irrants that are controlled by the state (Article 33 Paragraph (2) of the 1945 Constitution of the Republic of Indonesia) and in particular water based on Article 33 Paragraph (3) of the 1945 Constitution of the Republic of Indonesia (NKRI) used for the greatest prosperity of the people then the supervision and control by the state on water is absolute;

5. As a continuation of the right of control by the state and Since water is a resource which is very much in control of the livelihood of the people, the main priority given by the exploitation of water is a State Owned Enterprise or Regional Owned Enterprise;

6. If after all the above restrictions have been met and there is still water availability, the Government is still allowed to grant permission to private business entities to conduct water concessions under certain conditions and strict.

Implementation of Law Number 7 Year 2004 regarding Water Resources (hereinafter referred to as SDAir Law) can not be implemented in accordance with the conditions set by the Constitutional Court through the Court's decision No. 008 / PUU-III / 2005, so that the SDAir Law is canceled entirely by the Constitutional Court through Decision Number 85 / PUUXI / 2013 as well as the re-enactment of Law Number 11 Year
1974 on Irrigation. This cancellation resulted in changes to the laws and regulations regarding SPAM. Implementing regulations currently established are Government Regulation No. 122 of 2015 on Water Supply System (PP SPAM), in Article 36 and 42 of SPAM PP stated that in the implementation of SPAM can be established and implemented by: BUMN / BUMD, UPT / UPTD, Community Groups, and / or Business Entities. In this article can be described that the implementation of SPAM in the area can not only be done by BUMD, which is currently the PDAM but also can be implemented by SOEs, given some problems and constraints faced by PDAM as described in point A:

1. The very weak internal position of PDAM requires strengthening, both in financial, technical and human resources.

2. The threat to PDAM's performance is quite high, but PDAM has a chance high enough also that PDAM should be able to take advantage of opportunities that exist for minimize the threats that exist. There are many alternative sources financing the development of SPAM, but the PDAM does not have the capacity adequate to access these alternatives, so that the PDAM should can take advantage of investment opportunities by means of performance improvement management so that it will gain trust from the organizer these financing alternatives.

3. PDAM capacity needs to be improved to capture existing development opportunities, while the government also needs to open wider access to PDAMs on financing, institutional, and human resource development alternatives.

4. The PDAM faces complex problems, challenges and demands from the external side so that with weak PDAM conditions will not be able to improve its own performance. The division of responsibility for the management of SPAM units can be an alternative for PDAM management effectiveness to increase and PDAM can further improve the quality of its services to the community.

5. Improving the quality of these services will also increase the public confidence in the PDAM so that the number of subscribers will continue to grow and PDAM's revenue will also increase. This condition will improve the financial performance of PDAM.

Then the following will be analyzed the importance or urgency of the establishment of BUMN in drinking water sector in order to achieve $100 \%$ access to clean water and drinking water for all levels of Indonesian society without exception and capable and have the capability to manage the burden and risk of SPAM by PDAM. This will further enhance the main task of PDAM to serve the community better.

The provision of drinking water was a hybrid effort between social services but also needs to have a profit but also to ensure the sustainability of services of adequate quality. SPAM implementation in the form of Technical Implementation Unit (UPT) and Public Service Agency (BLU) would be more focused on service but not too consider on sustainable investment financing because there was no 
requirement for UPT / BLU to provide income for Government and financing which will always rely on Ministry budget.

The provision of SPAM in the form of BUMN is expected to guarantee the sustainability of financing for SPAM SPAINER in the region as the spearhead of drinking water services for the community. APBN as a capital participation for SOEs will be managed and invested by SOEs in the form of development

cooperation with PDAM-PDAM and other SPAM providers in the region so that the utilization of $A P B N$ is expected to be more efficient and effective and followed by improving the quality of service by regional SPAM organizers (PDAM) as the implication of reduced risk and responsibility in conducting SPAM.

The limitation of APBN becomes an obstacle in accelerating SPAM development in Indonesia. The disbursement of APBN has traditionally made the state expenditure uninterrupted by the absence of a "return" to the Government on the investment provided. The Government Capital Investment (PMP) in the state-owned drinking water company is expected to become an effort to manage, invest and rotate the PMP so that more SPAM developers in the region can benefit from the limited APBN.

It requires a body that can be a vocal point for PDAMs and other SPAM providers in the region in order to convey ideas, complaints, and responses to policies at the central level. It is hoped that this BUMN will have a closer position with the central government that issued the national policies related to the provision of SPAM so that it will be easier in discussing the policies related to SPAM developer in the region and conveying the aspiration of SPAM provider that has been difficult to be bridged.

Drinking Water State-Owned Enterprise (DWSOE) can act as the responsible of the Cooperation Agreement (PJPK) BUMN is one form of institution that can act as PJPK in the implementation of Government Cooperation project with Business Entity (KPBU) in accordance with Presidential Regulation no. 37 of 2015. One of the causes of difficult implementation of a CDE project in the drinking water sector is the difficulty of Local Government or PDAM as PJPK to negotiate with private parties. As a PJPK, SOEs are expected to be "partners" in a balanced negotiation with private parties, both in the aspects of human resources, financial, and technical capabilities.

The development and operation of raw water units and production units is carried out through a CDE scheme between drinking state enterprises and private parties. SOEs can act as Business Entities Implementing in a KPBU project. Besides acting as PJPK, DWSOE can also act as Business Entity (BUP) that cooperates with PDAM or Pemda in implementing KPBU project. It is expected that BUMN as BUP will be able to facilitate the realization of KPBU project since both are government owned enterprises. Government Support and Government Guarantee will also be easier to provide. BUMN drinking water in the form of persero can accommodate private funds in the form of shares. As a company, BUMN drinking water can utilize the funds from the private sector in the form of shares as the company's capital, yet $51 \%$ of the shares remain state-controlled. This scenario can be one of the alternative utilization of private financing which has been difficult to channel through the scheme of KPBU or other forms of cooperation.

Drinking Water State-Owned Enterprise can become the managers of regional SPAM systems across districts / cities as well as across provinces. New DWSOE can sell bulk water to several PDAM or other SPAM managers, either cross-district / city or even across provinces. It will also encourage the efforts of SPAM-based Water Region (water basin)

so that the availability, quality and quantity of potential raw water sources can be maintained and managed with the principle of justice for each region. The tariff of the bulk water was adjusted and may vary between PDAM. If the bulk water tariff is too high, the local government needs to subsidize it. DWSOE will be recommended to be directly under the State Ministry of State Owned Enterprises with the consideration that currently there is a discourse formation of holding DWSOE so it is expected that when the holding is realized then the state-owned drinking water will be easier to enter in the holding so that the financing of these DWSOE may come from the APBN in the form of PMP and / or derived from the funds in the holding. DWSOE in the form of Public Company and proposed under the sector of Water Supply, Waste Management and Recycling. Currently there has been Perum Jasa Tirta I and Perum Jasa Tirta II under the sector, but secondly DWSOE are more focused on the provision of raw water, while drinking state enterprises more directed to the supply of bulk water (processed water). The establishment and management of this DWSOE will refer to Law Number 19 Year 2003 on State-Owned Enterprises. The Ministry of StateOwned Enterprises will be the main institution who established the DWSOE. The establishment of this DWSOE will refer to Law Number 19 Year 2003 on State OwnedEnterprises.

Some of the main tasks of this Ministry of SOEs are:

Fostering drinking state enterprises;

Coordinate and synchronize the implementation of DWSOE coaching policies;

$>$ Manage the state property of DWSOE;

$>$ Supervised the performance of duties in DWSOE

Local Government is the owner of PDAMs, therefore the local government should strive to provide policy and budget support to PDAMs to ensure the sustainability of cooperation between BUMN Air Minum and PDAM. One of the budget support is the provision of tariff subsidies for drinking water. Other relevant stakeholders, in particular some related Ministries will be involved in formulating, establishing and implementing legislative legislation in the implementation of this cooperation as well as in ensuring the operational conformance of SPAM in BUMN or PDAM. These relevant ministries in accordance with their tupoksinya can provide increased support. 
BUMN Air Minum performs operational cooperation with PDAM. BUMN Drinking Water will sell bulk water (processed water) to PDAM. These forms of cooperation may adopt forms of cooperation in the Cooperation of Government and Business Entity (KPBU), such as Build-Operate-Transfer (BOT) if a new infrastructure development is necessary or a contract form governance and other forms tailored to the conditions of the PDAM. Cooperation BUMN - PDAM will be more Business to Business than the $\mathrm{CDEU}$ so that the process will be easier. This cooperation can be done by BUMN Air Minum with several PDAMs that are close together so that it can be a form of regional cooperation but the cooperation of BUMN - PDAM separated by the cooperation of BUMN - PDAM other.

It is a cooperative relationship between PDAM and its customers, in accordance with the tupoksi of the PDAM. Improving services to customers / communities will be the main focus of PDAMs. Clearly stated in Government Regulation no. 122 of 2015 on the Drinking Water Supply System Article 36 which states that the Central Government may establish SOEs in the framework of the implementation of SPAM to meet healthy, clean and productive life in accordance with the provisions of legislation. The establishment of these SOEs will assist the Central Government in exercising such authority and duties, such as managing part of SPAM, ensuring the availability of raw water, cooperating with the Regional Government, cooperating with business entities as well as providing guidance to SPAM providers in the regions.

Establishment and management of BUMN Air Drinking is supported by the availability of Law no. 19 of 2003 on StateOwned Enterprises. In this law it is explained that one form of BUMN that can be formed is a Public Company where all capital owned by the state and not divided into shares, which aims for public benefit in the form of provision of goods and / or services of high quality and pursues profit based on principles of management company. In addition, the SOE can also be a Persero or Persero Terbuka whose capital is divided into shares.

This is most in line with the purpose of implementing drinking water that promotes general benefit but must also have a "profit" to ensure service improvement and sustainability. In addition to aspects of performance improvement and improved access to drinking water, the establishment and operation of these new SOEs will require a political decision so that a strong legal foundation and feasibility study needs to be studied in more depth.

Performance conditions of about $50 \%$ of PDAMs are currently in "Less Healthy" and "Sick" status. Some of the "Healthy" PDAMs themselves are actually PDAMs whose performance is "Healthy" because many PDAMs are operating and trying without investing to accelerate the development and growth of their PDAMs, still about 75\% of PDAMs that have not yet been able to meet their revenues to cover operating costs and investment. This happens because of the complexity of the operation of a SPAM from upstream (raw water units) to downstream (service units) accompanied by the many demands and constraints faced by PDAMs both internally and externally. The transfer of a part of the burden and operational risk of a SPAM could be one of the alternatives for PDAMs to concentrate more on distribution units and services alone so that it is expected to improve PDAM's performance in providing services to the community.

Some technical aspects to consider in the formation of the DWSOE includes:

\section{Management of existing assets, assets to be built and asset transfer process.}

DWSOE needs to conduct technical studies on upstream infrastructure (raw water units to production units) so that it can know the existing technical performance and can determine the effort to improve the performance. One of the most important things is to conduct an energy audit. Division of financing, development and management responsibilities will be clear between DWSOE (upstream) and PDAM (downstream).

With this partnership, PDAM will concentrate more on financing, developing and managing downstream

infrastructure of service units.

For regional systems, policy support should be provided in the framework of the management of raw water with a system of water areas. DWSOE are national companies at the central level are expected to have easier access to request permits for the harvesting and management of water sources based on water areas so that there is no more sectoral conflict interest to the ownership of potential raw water sources. It is proposed that DWSOE can cooperate with river basin management in the provision of raw water for the purpose of drinking water supply. Definitely, this will require a review of policy and legal basis in more depth and may even require new policies and regulations.

The availability of development budgets in the sustainable SPAM sector is one of the key considerations in the development of DWSOE. Cooperation between DWSOE (companies owned by the Central Government) and PDAM (companies owned by the Regional Government) are expected to provide a revolving financial cycle as an uninterrupted state money or wealth. Social aspect becomes one of the aspects to be considered in the establishment of DWSOE. Generally, the establishment of DWSOE can cause social impact related to the increase of drinking water tariff to the customer. This tariff increasing needs to be anticipated, one of which is the subsidy of the bulk water tariff by the Central Government and the drinking water tariff subsidy by the Regional Government.

The management of raw water by DWSOE may occur because of the authority of the management of raw water sources by DWSOE can have a social impact on the management of water sources (eg rivers, springs, etc.) related to conflicts in the use of water resources such as by utilizing water sources for irrigation. This condition should be handled through good cooperation and coordination with the water resources management. Positive social impacts expected to arise from the establishment of the Drinking Water Company is the rapid increase in access to drinking water for the community that can improve the public health level in the 
service area. This increased health level will also increase the standard of living of the community so that it is expected to decrease the incidence of congenital diseases and increase the productivity of the people.

\section{CONCLUSION AND SUGGESTION}

Based on the analysis of internal and external conditions of SPAM management through theestablishment of the Drinking Water State-Owned Enterprise as described above, it can be concluded several things as below:

1. The establishment of a new DWSOE is worth and can be done in accordance with existing legislation but also need to consider various stages from planning, preparation and implementation. These stages include aspects of capital,human resources, and regulation.

2. Drinking Water State-Owned Enterprises can assist in the acceleration of development of drinking water services through their authority and capability in the management of raw water based on watershed areas, ability to coordinate with other institutions at the central level related to drinking water policy, their ability to cooperate with third parties through Government Cooperation scheme with Business Entity (KPBU/PPP), and its ability to provide knowledge sharing to improve PDAM capacity.

3. Drinking Water State-Owned Enterprises may have the authority to manage the Regional SPAM system across districts / municipalities as well as across provinces. In this regional system, DWSOE can apply different tariff of water for each taps depending on Willingness to Pay, Willingness to Connect, and Affordability to Pay from community in service area.

4. The establishment of the DWSOE will be expected to encourage the involvement of the Local Government and Central Government in the provision of drinking water through their respective contributions to capital and subsidies, such as subsidized water (central government) and subsidized water tariff (local government) by because the provision of access to drinking water is the responsibility of the government.

\section{ACKNOWLEDGMENT}

The authors wish to acknowledge to the Research Institute for Housing and Human settlements, Research and Development Agency, Ministry of Public Works and Housing, especially the Drinking Water and Environmental Health Settlements fot the full financial support of this research. Any views expressed in this paper are those of the authors and do not represent the policy of the Research Center and Development for Housing and Human settlements and other institutions that authors are affiliated with.

\section{REFERENCES}

[1] Agency for Improving the Implementation of Drinking Water Supply System (BPPSPAM), "Executive Summary : Buku Kinerja PDAM," Jakarta, Desember 2016.

[2] Central Bureau of Statistics (BPS), "Presentase Rumah Tangga Menurut Provinsi, Tipe Daerah dan Sumber Air Minum Layak, 2009-2016", Jakarta, Juni 2017.

[3] Santi. Puspitasari, Utari. Nindyaningrum, "Implikasi Putusan Mahkamah Konstitusi Nomor 865/PUU-XI/2013 Terhadap Sistem Penyediaan Air Minum", dalam JURNAL PENELITIAN HUKUM Vol. 2, Nomor 1, Fakultas Hukum Universitas Gadjah Mada Yogyakarta Maret 2015, hal. 45-61R.

[4] Laporan Hasil Survey Lapangan Kegiatan Penelitian dan Pengembangan Satuan Kerja Pusat Litbang Perumahan dan Permukiman Balitbang Kementerian PUPR : "Kajian Pemetaan Permasalahan Penyelenggaraan SPAM Pasca Dibatalkannya UU SDAir”, Bandung, 2017;

[5] Katalog BPS DIY 6206006, "Mewujudkan Aksesbilitas Air Minum dan Sanitasi yang Aman dan Berkelanjutan Bagi Semua - Hasil Survei Kualitas Air di Daerah Istimewa Yogyakarta”, ISBN : 978-602-438-0281, 04230.1608;

[6] Data BPS 2017, "Jumlah Air Bersih yang Disalurkan Perusahaan Air Bersih Menurut Provinsi (ribu m3)", 1995 - 2016, Jakarta, Juni 2016

[7] Kompas, Bisnis dan Keuangan "Menkeu : PPP ide yang bagus tetapi sulit diimplementasikan", www.bisniskeuangan.kompas.com, Septemnber, 2015);

[8] Yulistyorini, Anie, "Pemanenan Air Hujan Sebagai Alternatif Pengelolaan Sumber Daya Air di Perkotaan", dalam Jurnal Teknologi dan Kejuruan, Vo. 34, No. 1, Universitas Gadjah Mada Yogyakarta, Februari 2011 : 105-114

[9] Nasution. Bahder Johan, "Metode Penelitian Ilmu Hukum", Mandar Maju, Bandung, 2008, hal 124.

[10] World Bank, "Improving Effectiveness of Spending for Water and Sanitation in Indonesia", Water Supply and Sanitation Public Expenditure Review (WSS-PER), 2015

[11] Agency for Improving the Implementation of Drinking Water Supply System (BPPSPAM), "Kinerja PDAM 2015 Wilayah I, II, III dan IV," hal. 28-29 Jakarta, Oktober 2015.

[12] Al. Sentot Sudarwanto. "Dampak dibatalkannya Undang-Undang Nomor 7 Tahun 2004 tentang Sumber Daya Air Terhadap Manajemen Air untuk Kesejahteraan Masayarakat” Jurnal Hukum Yustisia. Edisi 92 Mei -Agustus 2015. Surakarta : Fakultas Hukum Universitas sebelas Maret DALAM Justicia M. Grace Istia, "Implikasi Pembatalan UndangUndang Nomor 7 Tahun 2004 tentang Sumber Daya Air Terhadap Perusahaan Pengelola Air (PDAM Kota Surakarta dan PT Tirta Investama Klaten, Jurnal Hukum Prival Law Vol. IV No. 2 Juli Desember 2016;

[13] ] ---------- 2016, “Konsep Ideal Regulasi Sumber Daya Air Untuk Mencegah Konflik Pemanfaatan Air dan Mencegah Bencana Hidrolgi”. Makal FGD Kelola Air, Cegah Bencana untuk Keberlanjutan Kehidupan Rakyat Indonesia yang Makmur dan Adil, 11 Februari 2016;

[14] Decision of the Constitutional Court Number 83 / PUU-XI / 2013, accesed on website : www.mahkamahkonstitusi.go.id; 